My Father's Journey

A Memoir of Lost Worlds of Jewish Lithuania 


\section{Studies in Orthodox Judaism}

\section{Series Editor}

Marc B. Shapiro (University of Scranton, Scranton, Pennsylvania)

\section{Editorial Board}

Alan Brill (Seton Hall University, South Orange, New Jersey)

Benjamin Brown (Hebrew University, Jerusalem)

David Ellenson (Hebrew Union College, New York)

Adam S. Ferziger (Bar-Ilan University, Ramat Gan)

Miri Freud-Kandel (University of Oxford, $0 x$ ford)

Jeffrey Gurock (Yeshiva University, New York)

Shlomo Tikoshinski (Jerusalem Institute for Israel Studies, Jerusalem)

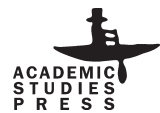




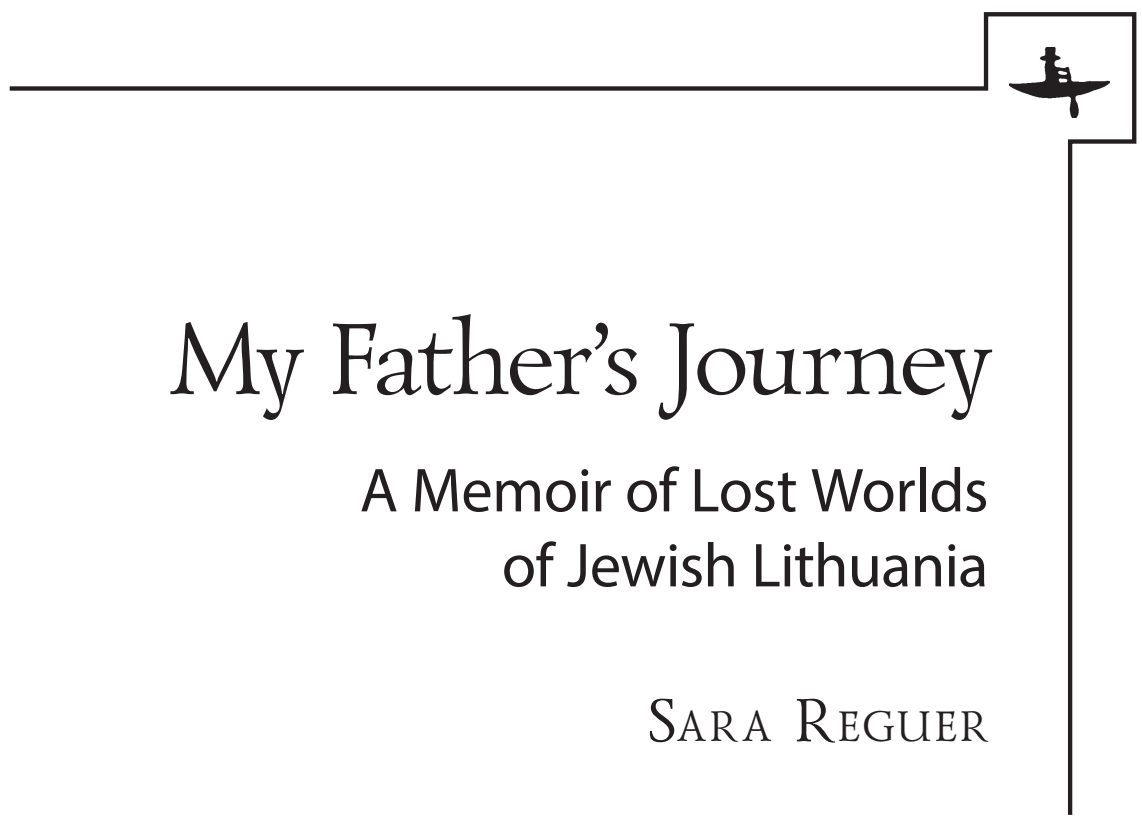

Boston

2015 
Library of Congress Cataloging-in-Publication Data:

A catalog record for this book as available from the Library of Congress.

Copyright ( 2015 Academic Studies Press

All rights reserved.

ISBN 978-1-61811-414-3 (hardback)

ISBN 978-1-61811-4150 (electronic)

Cover design by Ivan Grave.

On the cover: Watercolor portrait of Moshe Aron Reguer, entitled "He-Chalutz", by Thaddeus Rychter, Jerusalem, 1927; Photograph of Simcha Zelig Reguer and Moshe Aron Reguer, Brest-Litovsk, 1937. Courtesy of Sara Reguer.

Published by Academic Studies Press in 2015

28 Montfern Avenue

Brighton, MA 02135, USA

press@academicstudiespress.com

www.academicstudiespress.com 
In Xemory of

Xy parents

Moshe Aron Reguer

Anne Shabasson Reguer

Xy paternal grandparents

Simcha Zelig Reguer רוסוס"י הריסק קאים

Sorke Rudensky Reguer

And my aunts and cousins murdered by the Nazis in

Brest-Litousk in 1942. 
